MaPan : Jurnal Matematika dan Pembelajaran

p-ISSN: 2354-6883 ; e-ISSN: 2581-172X

Volume 8, No 2, Dec 2020 (205-223)

DOI: https://doi.org/10.24252/mapan.2020v8n2a3

\title{
ETHNOMATHEMATICS THOUGHT AND ITS INFLUENCE IN MATHEMATICAL LEARNING
}

\author{
Andi Saparuddin Nur1), Kartono'), Zaenuri'3), S B Waluya4), Rochmad5) \\ 1Pendidikan Matematika, Universitas Musamus; ${ }^{2,3,4,5}$ Pascasarjana Pendidikan \\ Matematika, Universitas Negeri Semarang \\ 1Jl. Kamizaun Mopah Lama, Merauke; 2,3,4,5Jl. Kelud Utara III, Semarang \\ E-mail: andisaparuddin@students.unnes.ac.id ${ }^{1)}$, kartono@mail.unnes.ac.id ${ }^{2),}$ \\ zaenuri.mat@mail.unnes.ac.id ${ }^{3)}$, s.b.waluya@mail.unnes.ac.id ${ }^{4}$, \\ rachmad_manden@mail.unnes.ac.id ${ }^{5}$
}

Received November 09, 2020; Revised December 04, 2020; Accepted December 18, 2020

\begin{abstract}
:
Mathematics is a symbol of rationality and the highest intellectual achievements of human civilization. Mathematics has always been seen as abstract and formal knowledge. However, in the last few decades, the idea has emerged that mathematics is a knowledge that develops in human cultural activities. The concept of mathematics in culture is widely known as ethnomathematics. This paper aims to briefly describe the history, criticism, and challenges of ethnomathematics, the thoughts of ethnomathematics experts, and their influence in learning mathematics today. The development of ethnomathematics gave rise to a field of study covering aspects of anthropology and the history of mathematics, non-formal mathematics practice, traditional mathematics, and multicultural learning. Various research results indicate that ethnomathematics contributes to improving school mathematics. Although culture has an important role in learning mathematics, to integrate it requires comprehensive efforts to overcome various obstacles. Teachers need to improve competencies related to understanding local culture to maximize the transformation of ethnomathematics learning in the classroom.
\end{abstract}

Keywords: Ethnomathematics, Cultural Mathematics, Mathematics Learning

\section{PEMIKIRAN ETNOMATEMATIKA DAN PENGARUHNYA DALAM PEMBELAJARAN MATEMATIKA}

\begin{abstract}
Abstrak:
Matematika merupakan simbol rasionalitas dan pencapaian intelektual peradaban tertinggi umat manusia. Matematika sejak dulu dipandang sebagai pengetahuan abstrak dan bersifat formal. Akan tetapi, dalam beberapa dekade terakhir muncul gagasan bahwa matematika merupakan pengetahuan yang berkembang di dalam aktivitas kebudayaan manusia. Konsep matematika di dalam budaya secara luas dikenal sebagai etnomatematika. Tulisan ini bertujuan untuk mendeskripsikan secara singkat sejarah, kritik dan tantangan etnomatematika, pemikiran-pemikiran para ahli etnomatematika serta pengaruhnya dalam pembelajaran matematika saat ini. Perkembangan etnomatematika memunculkan bidang kajian yang meliputi aspek antropologi dan sejarah matematika, praktik matematika non formal, matematika
\end{abstract}


tradisional dan pembelajaran multikultural. Berbagai hasil penelitian menunjukkan bahwa etnomatematika memberikan kontribusi terhadap peningkatan matematika sekolah. Meskipun budaya memiliki peran penting dalam pembelajaran matematika, namun untuk mengintegrasikannya perlu upaya komprehensif untuk mengatasi berbagai hambatannya. Guru perlu meningkatkan kompetensi terkait pemahaman budaya lokal untuk memaksimalkan transformasi pembelajaran etnomatematika di dalam kelas.

Kata Kunci: Etnomatematika, Matematika Budaya, Pembelajaran Matematika

How to Cite: Nur, A. S., Kartono, Zaenuri, Waluya, S. B., Rochmad. (2020). Ethnomathematics Thought and Its Influence in Mathematical Learning. MaPan : Jurnal Matematika dan Pembelajaran, 8(2), 205-223. https://doi.org/10.24252/mapan.2020v8n2a3.

\section{INTRODUCTION}

7 he development of mathematics as a compulsory subject throughout the world is a sign that mastery of its concepts is the most important means of achieving the advancement of civilization. Mathematics is the main instrument in every other field of knowledge such as engineering, agriculture, economics, even astronomy (D'Ambrosio, 1985). Mastering mathematics means providing opportunities for a civilization to show its existence. However, history also notes that the occurrence of colonialization in various parts of the world had an impact on the domination of Western (Eurocentric) culture. This condition for some experts cannot be separated from the mathematics brought by Europeans to their colonies using the Eurocentric way of thinking and ignoring the knowledge of indigenous peoples (Francois \& Kerkhove, 2010).

Mathematics is seen as the identity of culture and the greatest achievement of Europeans in conquering various regions of the world. The position of mathematics for hundreds of years has been seen as a symbol of the truth of rationality, the study of quantity, relations, and space has been challenged, especially when it comes to discussing mathematics and culture in the same sentence (Barton, 1990). The colonialization process provided the opportunity for Europeans to control the resources owned by their colony. However, mathematics, on the other hand, is the knowledge that is shared by all cultures but in different forms. This difference is seen in formalism, terminology, and philosophy which shows the existence of different mathematics known to Europeans. Folk mathematics or traditional 
mathematics is promoted by experts as ethnomathematics which has different characteristics from mathematics originating from the West.

The use of the term ethnomathematics provides an opportunity to study mathematics in indigenous peoples. Based on the PISA results, the ranking of countries from Asia, Africa, and Latin America is in the lowest position in terms of mastery of mathematical literacy (OECD, 2018). Most of these countries are former colonies of Europeans who accept Eurocentric mathematics in their practice of learning. Ethnomathematicians have the view that the mathematics that was formally brought by Europeans could not be understood by the indigenous people due to language and term barriers. On the other hand, there are more complex problems of a historical nature such as differences in political orientation, cultural domination, and racism.

The success of learning mathematics can be achieved if various components are considered in the pedagogical aspect including the student's cultural background. Using a cultural context allows students to explore mathematics more realistically. However, thinking about the cultural context of mathematics also has many critical questions and challenges that must be resolved. Criticism of ethnomathematics, especially on the question of differences in mathematics and ethnomathematics, the philosophy on which ethnomathematics is based, and how far culture can affect one's mathematical abilities.

Ethnomathematics experts try to show their position in the alternative philosophy of mathematics even though this shows that there are different perspectives in understanding the concept of ethnomathematics (Cimen, 2014). However, in the last three decades, it appears that ethnomathematics has had a fairly strong foothold in raising various issues, especially those related to multicultural mathematics learning, the integration of ethnomathematics in the curriculum, and indigenous mathematics. Besides, the topic of ethnomathematics has also been raised as a research study in actual mathematics education since CERME 2003 (Francois, 2010). Various ethnomathematics research studies around the world show serious efforts to consider the synergy between mathematics and culture that can be implemented in the classroom. This paper aims to briefly describe the history, criticism, and challenges of ethnomathematics, the thoughts of ethnomathematics experts, and their influence in learning mathematics today. 


\section{METHODS}

This research is a literature review that describes exploratively the history, criticism, challenges, ethnomathematics studies, and their effects on learning mathematics. The reference sources used are the results of research and ethnomathematics studies from international journals. The data collection technique was done by taking references to the Science Direct, Springer, and Taylor \& Francis. This is because publications on these sources have a very good reputation and are connected to the Scopus and the Web of Science index which have a high factor impact on research into the humanities social science cluster. The literature review procedure was carried out in 4 stages. The first stage of the search is carried out using the ethnomathematics subject area. The results obtained 136 documents in Science Direct, 948 documents on Springer, and 247 documents on Taylor \& Francis with publication years in the range 1980-2020. The second stage was carried out by sorting the documents based on studies on the clumps of mathematics education to obtain 92 documents in Science Direct, 616 documents on Springer, and 161 documents on Taylor \& Francis. The third stage is to do the sorting based on keywords, namely; history, criticism, challenges, and ethnomathematics studies and their influence in school mathematics learning so that 104 documents were obtained. The fourth stage was extracted data so that 40 documents were obtained as core references in the presentation of results and discussion. Data analysis was performed by examining the results of ethnomathematics reports from various sources and using them for research purposes.

\section{RESULTS AND DISCUSSION History of Ethnomathematics}

Starting a discussion related to history is not easy, not only because of the limited resources to describe the beginnings of ethnomathematics but also the concern that the references used are not representative. Therefore, ideas related to mathematics and culture were tried to be carried out from a chronological perspective where the Europeans began to realize that there was a power of mathematics outside their culture. The best example comes from Thomas Fuller, a black African slave who possessed extraordinary computational abilities (Fauvel \& Gerdes, 1990). Furthermore, there is Srinivasa Ramanujan from India who has very sharp mathematical intrusions which he obtained by himself (Christiansen, 2009). Mathematical power can be owned by anyone regardless of race, ethnicity, or social status. This is the basis 
for providing discourse related to mathematics that developed outside Western culture. Further implications will ultimately force us to debunk mathematics learning without using the attributes of social background, political orientation, and racial identity.

In 1956 Oswald Spengler put forward the idea of how mathematics develops in every culture (Barton, 1990). However, this idea has not been widely explored and studies to support it are lacking. The earliest investigations related to mathematics and culture began in the 1960s when Ascher started an investigation into the practice of mathematics in non-literate societies (Francois \& Kerkhove, 2010). In the 1970 ethnomathematics took a place in the international discussion of mathematics education but this idea was still seen by most people as a subject only possible for enrichment (Shirley, 2001). Initially, ethnomathematics was intended to distinguish the way non-literate societies use mathematics, but in its development, this dichotomy was deemed irrelevant and ethnomathematics was expanded not only to something exotic (Francois \& Kerkhove, 2010). Furthermore, D'Ambrosio initiated the term "ethnomathematics", where ethno has a broad meaning by including all certain cultural groups with jargon, symbols, myths, and ways of thinking (D'Ambrosio, 1985). Ethnomathematics refers to several ideas related to the history of mathematics, cultural roots of mathematics, implicit mathematics used in certain professional contexts, and mathematics education (Vithal \& Skovsmose, 1997). This view also emphasizes the position of ethnomathematics as "alternative mathematics" which has a different philosophy from mathematics which has been known and has started a space for academic discussion so that it can be applied in the curriculum.

\section{Ethnomathematical Criticism and Challenges}

The emergence of ethnomathematics is inseparable from attempts to criticize the philosophy of mathematics that has existed for hundreds of years. The failure of mathematics education that is experienced, especially in former colonial countries, illustrates the need for an alternative philosophy as a matter of debate (Barton, 1990). Mathematics looks rigid and seems to be separate from human activities, giving rise to efforts to rediscover the nature of mathematics learning from a different perspective. Mathematics is like a platonic view which considers ideas in the mind to object that cannot be formalized, while ethnomathematics places humans, including their culture, as an important feature for the development of mathematics (Pais, 2011). 
Ethnomathematics is a method used to capture mathematical ideas from a cultural perspective (Adam, Alangui, \& Barton, 2003). Generative culture can be defined as the whole process of human communication activities (Anderson-pence, 2015).

Epistemologically, ethnomathematics has received a lot of criticism by using the results of the ethnomathematics research program which is considered the most influential (Pais, 2011). Critics of ethnomathematics epistemology include those made by (Rowlands \& Carson, 2002) who questioned the position of ethnomathematics as a new topic in mathematics related to pedagogical practice and its possibility in the overall curriculum which was then responded to by (Adam, Alangui, \& Barton, 2003). According to Rowlands and Carson (2002) mathematics is universal so that cultural aspects must affect mathematics, however, culture does not determine the truth of mathematics. Comment Adam, Alangui, and Barton (2003) ethnomathematics is not a pedagogical philosophy, but indigenous knowledge needs to be protected, promoted, and valued through the unique means that they use.

According to Barton (1996), three dimensions confuse ethnomathematical epistemology regarding the meaning of words used to explain ideas about culture and mathematics, namely: international discipline problems, philosophical difficulties, and their relation to mathematics itself. Critics of ethnomathematics are also based on the view of cultural relativity against cultural independence and the universality of mathematics (Cimen, 2014). The universality of mathematics is a part that is often questioned by anthropologists when discussing ethnomathematics research (Zhang \& Zhang, 2010). This tension has led to a confluence of educational flows between globalization and cultural diversity (Pais, 2011). So far, school mathematics shows the impression of imposing one culture on another, in this case, the only mathematics that is accepted is that of the West (Knijnik, 2012).

Mathematics as humankind's greatest academic achievement has little to do with socio-political origins or cultural identity, on the contrary, it has much to do with the pragmatic values of each group (Zhang \& Zhang, 2010). Rowlands and Carson in Pais (2011) views ethnomathematics knowledge cannot be brought to the classroom because basically, mathematics is a foreign language for every student. A school is a place where people interact with a more universal culture that allows one to master various cultures. This view contradicts the ethnomatistic attitude that assumes that students, before 
leaving for school, have non-formal mathematical knowledge in their original cultural environment. The mathematical ideas of traditional societies are not static but evolve which gives us new knowledge and concepts in mathematics (Adam, Alangui, \& Barton, 2003). The idea of mathematics as a product leads us to the essence of mathematics which has universal, eternal, and valid meaning (Vilela, 2010).

Ethnomathematics has a close relationship between mathematics education and social and cultural backgrounds, but some problems do not appear to be fully related to school mathematics (Zhang \& Zhang, 2010). Ethno-mathematical ideas in schools can serve as a development of local and practical knowledge for students but do little to help compete in increasingly fierce academic mathematics. Ethnomathematics studies provide an anthropological portrait of how mathematics is propagated and used in certain practices (Vilela, 2010).

Understanding ethnomathematics from a philosophical point of view can use the Wittgenstein approach, namely linguistic practice, and humanistic focus. According to Wittgenstein in Vilela (2010), mathematics is synonymous with language that is born from the human mind in various contexts and uniquely correlated world images. Furthermore, the philosophical foundation of ethnomathematics according to Wittgenstein is related to the humanistic focus, namely culture, and civilization. Culture relates to the human soul with its spiritual, custom, and aesthetic dimensions. Meanwhile, civilization deals with intelligence, rationality, materiality, and the functionality of human life. Another figure of ethnomathematics philosophy, namely, Michel Foucault. Foucault's contribution to the ethnomathematics perspective is the idea of discourse, power, resistance, and counter-behavior (Knijnik, 2012). According to Foucault, mathematics was discouraged as a form of European cultural domination in its colony, which gave rise to intellectual power. This domination caused resistance because of the clash of identities that were deemed not representative of the intellectual property of the local culture. This form of resistance is manifested in the form of counter attitudes and trying to provide alternative ideas to existing mathematical concepts. Foucault's idea gave rise to a progressive ethnomathematics philosophy that not only affects the educational dimension but also social and political dimensions. 


\section{Ethnomathematics Studies}

Ethnomathematics has been a rapidly growing field of study for decades. His discussion has attracted the attention of many mathematics education experts to contribute to the development of this study. According to Vithal and Skovsmose (1997), ethnomathematics studies can be divided into 4 fields, namely: 1) The study of criticism of the history of mathematics is too centered on the development of mathematics in Europe and ignores mathematics that developed in other societies. 2) The study of mathematical practices in marginalized traditional cultures. This research is often found in the form of anthropological and ethnographic research. 3) The study of the application of mathematics in various professional contexts, community, gender, age levels, and certain social environments. 4) Studies that focus on the possibility of ethnomathematics are included in the curriculum. Various studies in this field use the term multicultural curriculum to describe the relationship between ethnomathematics and mathematics education. In general, ethnomathematics studies and their dimensions can be seen in figure 1.

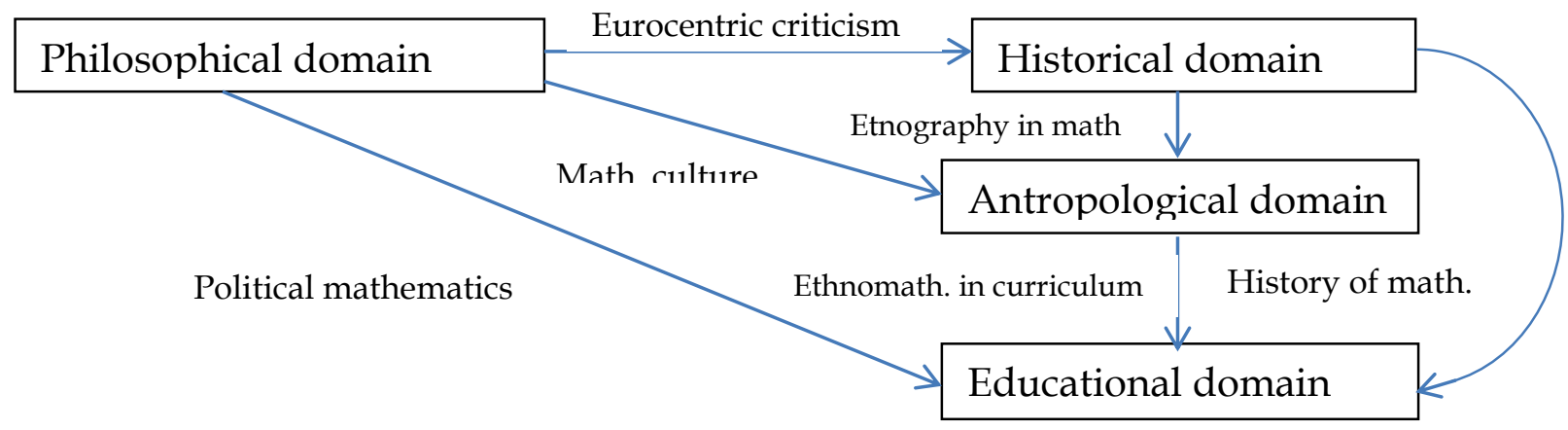

Figure 1. Ethnomathematics Studies

Furthermore, according to Francois and Kerkhove (2010) the domain of ethnomathematics research includes: 1) Anthropological domain, including mathematical practices in non-western cultures that have existed since colonialization and continued in traditional culture. The focus of ethnomathematics studies that use the anthropological side of culture lies in the descriptions and ideas behind the practice. 2) A historical domain includes critical attitudes towards the development of mathematics which reminds us of mathematical eurocentrism. The definition of Eurocentrism means that the mathematics that is developing today is an idea originating from Europe and as a form of superiority in each of its colonies so that it ignores traditional 
mathematics. 3) The domain of philosophy, this study is based more on theory, knowledge, cultural methods, cognitive studies, linguistics, and anthropology. and 4) Educational domain, this study is the estuary of the entire ethnomathematics study domain.

Ethnomathematics experts have different interests in the study, causing different paradigms in looking at mathematics and ethnomathematics. These differences enrich the object of study and further sharpen the understanding of mathematics in a cultural context. Some comparisons of expert viewpoints related to mathematics and ethnomathematics (Barton, 1996; Cimen, 2014; Parsons, 2018) can be seen in table 1.

Table 1. Comparison of mathematics and ethnomathematics based on the viewpoint of experts

\begin{tabular}{|c|c|c|}
\hline & Mathematics & Etnomathematics \\
\hline D’Ambrosio & $\begin{array}{l}\text { Knowledge is free from } \\
\text { experience, a knowledge } \\
\text { system that changes } \\
\text { through } \\
\text { activity. }\end{array}$ & $\begin{array}{l}\text { Knowledge depends on experience, } \\
\text { continuous interaction with } \\
\text { community members, taught } \\
\text { informally and practices. }\end{array}$ \\
\hline Gerdes & $\begin{array}{l}\text { Mathematics based on a } \\
\text { western worldview. }\end{array}$ & $\begin{array}{l}\text { Using indigenous culture as a } \\
\text { viewpoint, mathematics is related } \\
\text { to society. }\end{array}$ \\
\hline Ascher & $\begin{array}{l}\text { It is explicitly defined as } \\
\text { knowledge particular to } \\
\text { western culture. }\end{array}$ & $\begin{array}{l}\text { Mathematical thinking is a cultural } \\
\text { context that is not limited to ideas } \\
\text { but is applied. }\end{array}$ \\
\hline Powell & Eurocentric mathematics. & 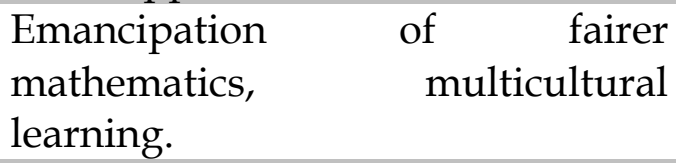 \\
\hline Bishop & $\begin{array}{l}\text { Formal mathematical } \\
\text { knowledge. }\end{array}$ & $\begin{array}{l}\text { Mathematics develops as a product } \\
\text { of the culture in human activities. }\end{array}$ \\
\hline Pompeu & $\begin{array}{l}\text { Known mathematics in } \\
\text { the western world. }\end{array}$ & $\begin{array}{l}\text { Mathematical knowledge or } \\
\text { mathematical activity known to } \\
\text { specific cultural groups. }\end{array}$ \\
\hline Knijnik & $\begin{array}{l}\text { Free from the socio- } \\
\text { cultural context, it is } \\
\text { formal and universally. }\end{array}$ & $\begin{array}{l}\text { Investigation of mathematical } \\
\text { traditions, practices, and concepts } \\
\text { in social heritage. }\end{array}$ \\
\hline Lipka & $\begin{array}{l}\text { A collection of logical } \\
\text { propositions representing } \\
\text { the ideal world, } \\
\text { mathematics as science } \\
\text { and theory. }\end{array}$ & $\begin{array}{l}\text { Mathematical concepts are woven } \\
\text { from the knowledge of indigenous } \\
\text { cultural practices. }\end{array}$ \\
\hline
\end{tabular}


Ascher is practitioners who places ethnomathematics as an applied subject, not just an idea. Many of his writings show the application of mathematics in various cultures. However, Ascher has not shown how the relationship between mathematics and culture can be applied in classroom learning. At least from tracing the results of Ascher's research, we can conclude that his studies are more related to the domain of anthropology and the history of mathematics. Ascher views ethnomathematics as a separate field from mathematics using non-literate and traditional terms (Barton, 1996). Meanwhile, in his various research results, Gerdes was relatively the same as the field of a study conducted by Ascher, but the political position of mathematics began to appear in some of his writings. Gerdes linked ethnomathematics to "folk mathematics" which implies a difference with contextual mathematics. Gerdes explicitly stated the importance of including culture in mathematics curriculum and its relation to several educational issues in Africa.

Pompeu in his writings views ethnomathematics as a mathematical concept of culture or social activity unknown to western anthropologists (Cimen, 2014). The anthropological dimension is a study that represents Pompeu's ideas on ethnomathematics. D'Ambrosio is a central figure who has a broad view of ethnomathematics by writing various studies related to socioanthropology between society and mathematics (D'Ambrosio, 2002, 1985). The results of his thinking can be said to be able to move academics to start questioning the philosophy of mathematics and contribute to ethnomathematics studies. In various writings, ethnomathematics is seen as a type of knowledge that is different from mathematics. Meanwhile, Knijnik more studies ethnomathematics from a philosophical point of view which has an impact on the political position of mathematics. Knijnik does not use cultural terms to discuss specific groups of entities but uses terms from social groups that are more political in nature (Cimen, 2014).

Ethnomathematics studies related to educational dimensions, some of which are the research program conducted by Lipka (Parsons, 2018). Lipka promotes culturally-based mathematics among indigenous communities in Alaska. Meanwhile, Bishop views mathematics as a result of human activity and develops in every culture (Bishop, 1994). Research evidence from anthropological and cross-cultural studies has emerged not only to support those mathematics has a cultural history, but also that different cultural histories have represented different mathematics. The anthropological 
perspective of mathematics education will show two processes, namely enculturation, and acculturation. The enculturation process is related to the integration of students with their own culture while on the other hand, the acculturation process is related to the integration of students with foreign cultures that are outside their environment (Bishop, 1988). Multicultural learning has become an educational issue in the United States to reduce intellectual violence between white and black races (Powell, 2002). This concept was initiated by using a culture-based learning approach. Powell examines ethnomathematics from the political perspective of mathematics education.

\section{Ethnomathematics Research Trends}

The development of ethnomathematics studies is very fast, not only in developing countries but in OECD countries also providing great exploration opportunities for this field. The development of ethnomathematics throughout the world has led to research trends that can be identified from the subject of study. At present, ethnomathematics is experiencing a transitional phase from being limited to the concept of combining mathematics and culture to be integrated with a culture-based mathematics curriculum. This will have a major impact on the broader application of ethnomathematics in pedagogical practice and provide opportunities for teachers and students to develop various culture-based learning methods.

The progressive steps in recent years can be seen from the writing of Rosa \& Orey on a concept called ethnomodeling (Rosa \& Orey, 2011, 2016a, 2016b, 2018). Ethnomodeling considers a variety of symbolic constructions and the development of scientific knowledge that gives rise to the possible role of culture in solving problems (Rosa \& Orey, 2016a). Ethnomodeling is an approach that elaborates on the relationship between cultural heritage and mathematical models (Rosa \& Orey, 2013). The disciplines covered in it are mathematical modeling, cultural anthropology, and ethnomathematics (Rosa \& Orey, 2018). Ethnomodeling is a method that teachers can use to verify their cultural knowledge even though they do not come from the student's cultural group. Rosa \& Orey use the terms emic and etic to denote the culture that students have and the culture brought by teachers (Rosa \& Orey, 2018). This concept is very argumentative showing how ethnomathematics can enter the classroom not only about students' refusal to learn their own culture, but also 
the ability of teachers to teach mathematics according to student culture without being influenced by the culture it carries.

Ethnomodeling can be defined as a culture-based model that is used to facilitate concepts with knowledge systems taken from daily cultural interactions (Rosa \& Orey, 2018). Examples of the application of ethnomodels in learning mathematics include using geometric principles in various crafts, architectural concepts, calculation techniques, forecasting, numerical systems, and understanding patterns. The use of ethnomodeling in the classroom provides opportunities for students to explore mathematical methods used in their cultural environment.

Ethnomathematics research projects are also developing in the United States, some of which are multicultural learning. Multicultural learning bridges mathematics with cultural connections and is no longer an enrichment (Shirley, 2001). The multicultural approach is a part of ethnomathematics research that has become a hallmark in the last few decades which aims to accommodate cultural diversity in society to enter the school environment (Pais, 2011). The United States is the most multicultural country in the world with a history of education that cannot be separated from racial issues and has produced various negative effects. Reconciliation and constructive efforts using culture-based learning have shown significant results on traditional mathematical knowledge (Pinxten \& François, 2011; Powell, 2002; Prieto \& Claeys, 2015). This also at the same time relieves the tension experienced by students in the classroom by providing wider acceptance of differences in social and cultural backgrounds.

The integration of ethnomathematics in the form of a curriculum that accommodates indigenous peoples is a study that is widely carried out in various countries today. Each country has a unique and complex sociopolitical context in determining education policy, particularly in protecting indigenous peoples' knowledge systems (Aikenhead, 2017). The ethnomathematics research project in Alaska is the Mathematical Cultural Context (MCC) which uses indigenous peoples' knowledge systems in the fields of ethnography, mathematics, cosmology, epistemology, axiology, and pedagogy in learning (Parsons, 2018). In Norway, curriculum development that accommodates the culture of the Sa'mi people is done by reducing the dominance of the national curriculum. The indigenous culture-based curriculum and ethnomathematics teaching provide opportunities for students to develop a strong cultural identity and study mathematics based on their 
culture (Nutti, 2016). Special education for indigenous peoples has become a government program in Brazil as well as developing a mathematics curriculum in a bilingual context for numerics and literacy (Mendes, 2005).

It is realized that the ethnomathematics curriculum will succeed if the teacher has the competence to teach it in the classroom well. This has led to the emergence of case studies related to ethnomathematics problems in teaching teacher education (Verner, Massarwe, \& Bshouty, 2013). Several universities in Israel started ethnomathematics programs for prospective teachers. This effort is made so that the application of ethnomathematics can run as expected when prospective teachers are ready to teach in school. Learning practices are carried out using constructivist culture-based methods to motivate students to learn to use their context and to be involved in various ethnomathematics projects, especially geometry (Verner, Massarwe, \& Bshouty, 2013). The responses given by prospective teachers and students are very open to ethnomathematics learning. This program is the first step in preparing a culture-based mathematics curriculum and becomes the agenda proposed in the development of the Israeli mathematics curriculum (Verner, Massarwe, \& Bshouty, 2013).

Various researches currently focus their studies on integrating ethnomathematics with the curriculum (Francois \& Kerkhove, 2010). Ethnomathematics integration into the curriculum can be done by using cases of cultural context (Zhang \& Zhang, 2010). For example, the use of traditional games, mathematics applied to non-formal professions, the context of folklore, cultural products, and indigenous peoples' knowledge systems.

\section{Implementation of ethnomathematics in learning}

The synergy between values and mathematics can be seen from two perspectives, the first discuss curriculum issues related to what and how mathematics is taught in the social context of students and the second discusses the pedagogical practice of how to teach mathematics (Boylan, 2016). Teachers need to consider ethnomathematics entering the classroom that mediates formal knowledge with different experiences and cultural backgrounds for each student (Anderson-pence, 2015). Mathematical thinking is influenced by the diversity of the human environment and its elements so that logical processes which include measurement, quantity, and modeling explain their context in their position with the natural surroundings (Rosa \& Orey, 2016a). 
Ethnomathematics cannot replace mathematics, but its existence is very effective for use in learning practices and reflects on it as a form that contributes to culture (Adam, Alangui, \& Barton, 2003). Ethnomathematics suggests that the material is associated with the cultural roots of the community that are familiar to students, but not only limited, ethnomathematics can also be applied to various mathematical practices used by certain groups (Vithal \& Skovsmose, 1997). Ethnomathematics is very important for prospective mathematics teachers to keep an open mind (Adam, 2010; Shirley, 2001). Ethnomathematics provides recognition of the uniqueness of traditional culture by reviewing complex knowledge systems so that they can maintain their existence in a sustainable manner (Adam, Alangui, \& Barton, 2003). For example, the mathematics used by carpenters to make ethnomathematics from carpenters, the mathematics used by street child sellers, the mathematics used by craftsmen, or mathematics used by indigenous peoples so that ethnomathematics becomes an applicable concept in various unique contexts.

The ethical dimension in mathematics learning needs to consider aspects of the relationship with society, culture, ecology, and oneself (Boylan, 2016). Culture applies at every level of education both in society, schools, and classrooms. Learning in the classroom is largely determined by the type of experience students get in society (Anderson-pence, 2015). The subject solution strategy consists of two aspects, namely mathematical problems presented in the context of the school giving rise to formal and context-free strategies, while computational activities outside of school give rise to informal and contextdependent strategies (Verschaffel, Corte, \& Lasure, 1994).

Some research results show that mathematics learning is more effective if examples are taken from a certain cultural context (Barton, 1996). Mathematics as the knowledge that comes from human culture is involved in six universal activities, namely: counting, searching, measuring, designing, playing, and explaining (Bishop, 1988). The ethnomathematics knowledge system is about finding or revealing various things related to mathematical elements (Adam, 2010). Bringing the socio-cultural context of students to the classroom can be done by posing realistic problems with everyday mathematics practices such as buying and selling, sewing, weaving, carpentry, wholesale packaging, and others (Verschaffel, Corte, \& Lasure, 1994). Culturerelevant learning aims to produce students who can achieve academic achievements, can demonstrate cultural competence, and develop students 
who can understand and criticize existing social orders (Anderson-pence, 2015).

Many countries with sizeable indigenous peoples increasingly understand the benefits of using indigenous knowledge systems, activities, and perspectives to improve school mathematics (Aikenhead, 2017). This condition is also felt important in Indonesia which has several cultural problems because it consists of many ethnic groups and cultures. The problem of education in Indonesia can be seen from the fading of local cultural characters amidst modernization and a lack of respect for customary values. By integrating culture into mathematics learning, it is hoped that students can learn meaningfully and help students improve their understanding (Peni, 2019). Teachers help students demonstrate cultural competence through positive interactions in the classroom by forming communication spaces that are mutually respectful (Anderson-pence, 2015).

Although important culture is included in the mathematics learning process, it is difficult to implement. According to Peni (2019), there are 4 obstacles to developing culture-based mathematics learning, namely: 1) value barriers related to student ideology and interests, 2) barriers to the power of innovation to shift the existing balance, 3) practical barriers, and 4) barriers psychological. Furthermore, the use of language appropriately is something that cannot be ignored by the teacher, especially if students come from environments that use more than one language. Language as a cultural identity cannot be separated from its influence on the learning process of mathematics (Stathopoulou \& Kalabasis, 2006). Students' understanding depends on the language used to learn a mathematical concept (Kim, Ferrinimundy, \& Sfard, 2012). The difference in discourse between everyday language and formal mathematics is something that must be realized by teachers in their learning. Language as a series of communication determines identity, and the nature of oral traditions contributes to efforts to bridge culture with mathematical concepts (Stathopoulou \& Kalabasis, 2006).

\section{CONCLUSION}

The problem of low mathematical ability in a country that was once colonized and the lack of sensitivity of cultural-based pedagogical ideology has led to the emergence of the idea of combining mathematics and culture which is called ethnomathematics. Although ethnomathematics has been criticized and challenged regarding its philosophical foundation and its 
position in the study of mathematics education, in reality, the issue of alternative learning for indigenous and minority communities still makes ethnomathematics an interesting study in various countries. Various streams in ethnomathematics are very likely to be influenced by the visions, methods, and perspectives used to present mathematical concepts in various cultures. Ethnomathematics has become a new paradigm in mathematics education that uses culture as a knowledge structure. However, the ethnomathematics journey as an alternative pedagogical concept still requires various efforts to be integrated into the curriculum. Ethnomathematics research studies currently have a very open opportunity in the dimensions of application in the classroom. Therefore, mathematics learning should pay attention to sociocultural aspects by linking various contextual problems that exist in the environment around students. On the other hand, teachers as the spearhead of education also need to be prepared for the sustainability of the ethnomathematics program. The ability of indigenous peoples' cultural knowledge and aspects of language is an important factor for the success of ethnomathematics learning.

\section{REFERENCES}

Adam, N. A. (2010). Mutual interrogation: a methodological process in ethnomathematical research. In International Conference on Mathematics Education Research, 8, 700-707). https://doi.org/10.1016/j.sbspro.2010. 12.097.

Adam, S., Alangui, W., \& Barton, B. (2003). A comment on: rowlands \& carson "where would formal, academic mathematics stand in a curriculum informed by ethnomathematics? A Critical Review" 1. Educational Studies in Mathematics, 52, 327-335. https://doi.org/10.1023/A: 1024308220169.

Aikenhead, G. S. (2017). Enhancing school mathematics culturally: a path of reconciliation. Canadian Journal of Science, Mathematics and Technology Education, 17(2), 73-140. https://doi.org/10.1080/14926156.2017. 1308043.

Anderson-pence, K. L. (2015). Ethnomathematics: the role of culture in the teaching and learning of mathematics. Utah Mathematics Teacher Fall/Winter. Retrieved from https://www.researchgate.net/publication /280865220.

Barton, B. (1990). Ethnomathematics and philosophy. ZDM, 99(2), 54-58. https:/ / doi.org/10.1007/s11858-999-0009-7.

Barton, B. (1996). Making Sense of ethnomathematics: ethnomathematics is making sense. Educational Studies in Mathematics, 31, 201-233. https:// 
doi.org/10.1007/BF00143932.

Bishop, Alan J. (1988). Mathematics education context in its cultural. Educational Studies in Mathematics, 19(2), 179-191. Retrieved from http: //www.jstor.org/stable/3482573.

Bishop, Alan J. (1994). Cultural conflicts in mathematics education: developing a research agenda. For the Learning of Mathematics, 14(2), 15-18. Retrieved from http://www.jstor.org/stable/40248109.

Boylan, M. (2016). Ethical dimensions of mathematics education. Educational Studies in Mathematics, 1-15. https://doi.org/10.1007/s10649-015-9678$\mathrm{z}$.

Christiansen, A. (2009). The beauty and sprituality of mathematics: a review essay. International Journal of Education $\mathcal{E}$ the Arts, 10. Retrieved from http:/ /www.ijea.org/v10r2/.

Cimen, O. A. (2014). Discussing ethnomathematics: is mathematics culturally dependent? Procedia - Social and Behavioral Sciences, 152, 523-528. https:// doi.org/10.1016/j.sbspro.2014.09.215.

D'Ambrosio, U. (2002). Cultural framing of mathematics teaching and learning. in A.J. bishop (Ed.), Didactics of Mathematics As A Scientific Discipline. pp. 443-455. New York: Kluwer Academic Publisher.

D'Ambrosio, U. (1985). Ethnomathematics and its place in the history and pedagogy of mathematics. For the Learning of Mathematics, 5(1), 44-47. Retrieved from https://scinapse.io/papers/316331165.

Fauvel, J., \& Gerdes, P. (1990). African slave and calculating prodigy: bicentenary death of thomas fuller. Historia Mathematica, 17, 141-151. https:/ / doi.org/10.1016/0315-0860(90)90050-N.

Francois, K. (2010). The role of ethnomathematics within mathematics education. Proceedings of CERME 6, January 28th-February 1st 2009, Lyon France (pp. 1517-1526). INRP.

Francois, K., \& Kerkhove, B. Van. (2010). Ethnomathematics and the philosophy of mathematics (education). Philosophy of Mathematics: Sociological Aspects and Mathematical Practice., 11(February), 121-154. Retrieved from https://www.semanticscholar.org/paper/Ethnomathe matics-and-the-philosophy-of-mathematics-Fran-Kerkhove/7160058c47 18e92ae1728b528624255f1f770b2f?p2df.

Kim, D., Ferrini-mundy, J., \& Sfard, A. (2012). How does language impact the learning of mathematics? comparison of english and Korean speaking university students discourses on infinity. International Journal of Educational Research, 51-52, 86-108. https://doi.org/10.1016/j.ijer.2012. 01.004 .

Knijnik, G. (2012). Differentially positioned language games: ethnomathematics from a philosophical perspective. Educational Studies in Mathematics, 80(July), 87-100. https://doi.org/10.1007/s10649-012- 
9396-8.

Mendes, J. R. (2005). Numeracy and literacy in a bilingual context: indigenous teachers education in Brazil. Educational Studies in Mathematics, 64, 217230. https:/ / doi.org/10.1007/ s10649-005-9009-x.

Nutti, Y. J. (2016). Decolonizing indigenous teaching: renewing actions through a critical utopian action research framework. Action Research Journal, 10(1), 1-23. https:/ / doi.org/10.1177/1476750316668240.

OECD. (2018). PISA 2015: Results in focus. Pisa 2015, (67), 16. https://doi.org/ 10.1787/9789264266490-en.

Pais, A. (2011). Criticisms and contradictions of ethnomathematics, (December 2010), 209-230. https:/ / doi.org/10.1007/s10649-010-9289-7.

Parsons, K. (2018). A yup'ik research framework: center, a place to begin. Proceedings from the Alaska Native Studies Conference. Alaska: University of Alaska.

Peni, N. R. (2019). Development framework of ethnomathematics curriculum through realistic mathematics education approach. IOSR-JRME, 9(4), 16-24. https:// doi.org/10.9790/1959-0904011624www.iosrjournals.org.

Pinxten, R., \& Francois, K. (2011). Politics in an Indian canyon? some thoughts on the implications of ethnomathematics. Educ Stud Math, 78, 261-273. https:/ / doi.org/10.1007/s10649-011-9328-z.

Powell, A. B. (2002). Ethnomathematics and the challenges of racism in mathematics education. Proceedings of the Third International MES Conference. Copenhagen: Centre for Research in Learning Mathematics, pp. 1-15. USA: Rutgers University.

Prieto, L., \& Claeys, L. (2015). Transnational alliances: la clase magica nepohualtzitzin ethnomathematics club, 125-134. https://doi.org/ 10.1080/15348431.2015.1011470.

Rosa, M., \& Orey, D. C. (2011). Ethnomathematics: the cultural aspects of mathematics etnomatematica: os aspectos culturais da matematica. Revista Latinoamericana de Etnomatematica, 4(2), 32-54. Retrieved from http://funes.uniandes.edu.co/3079/.

Rosa, M., \& Orey, D. C. (2013). Ethnomodelling as a research lens on ethnomathematics and modelling. Teaching Mathematical Modelling: Connecting to Research and Practice, 117-127. Switzerland: Springer Science+Business Media Dordrecht. https://doi.org/10.1007/978-94007-6540-5.

Rosa, M., \& Orey, D. C. (2016a). Humanizing mathematics through ethnomodelling humanizing mathematics through ethnomodelling. Journal of Humanistic Mathematics, 6(2), 3-22. https://doi.org/10.5642/ jhummath.201602.03.

Rosa, M., \& Orey, D. C. (2016b). State of the art in ethnomathematics. ICME-13 Topical Surveys. pp. 11-37. https://doi.org/10.1007/978-3-319-30120-4. 
Rosa, M., \& Orey, D. C. (2018). The anthropological dimension on ethnomodelling research based on ethnomathematics and modelling. Journal of Archaeology and Anthropology, 1(1), 1-8. http://dx.doi.org/ 10.33552/OAJAA.2018.01.000503.

Rowlands, S., \& Carson, R. (2002). Where would formal, academic mathematics stand in a curriculum informed by ethnomathematics? a critical review of ethnomathematics. Educational Studies and Mathematics, 50, 79-102. https://doi.org/10.1023 / A:1020532926983.

Shirley, L. (2001). Ethnomathematics as a fundamental of instructional methodology. ZDM, 33(3), 85-87. https:// doi.org/10.1007/BF02655699.

Stathopoulou, C., \& Kalabasis, F. (2006). Language and culture in mathematics education: reflections on observing a romany class in a greek school. Educational Studies in Mathematics, 64, 231-238. https://doi.org/10.1007 /s10649-006-4496-y.

Verner, I., Massarwe, K., \& Bshouty, D. (2013). Constructs of engagement emerging in an ethnomathematically-based teacher education course. Journal of Mathematical Behavior, 32(3), 494-507. https://doi.org/10.1016 /j.jmathb.2013.06.002.

Verschaffel, L., Corte, E. D. E., \& Lasure, S. (1994). Realistic considerations in mathematical modeling of school arithmetic word problems. Learning and Instruction, 4, 273-294. https://doi.org/10.1016/09594752(94)90002-7.

Vilela, D. S. (2010). Discussing a philosophical background for the ethnomathematical program. Educational Studies in Mathematics, 75, 345358. https://doi.org/10.1007/s10649-010-9261-6.

Vithal, R., \& Skovsmose, O. L. E. (1997). The end of innocence: a critique of ethnomathematics. Educational Studies in Mathematics, 34, 131-158. https:// doi.org/10.1023/A:1002971922833.

Zhang, W. \& Zhang, Q. (2010). Ethnomathematics and its integration within the mathematics curriculum. Journal of Mathematics Education, 3(1), 151157. Retrieved from http://educationforatoz.com/images/_12_ Weizhong_Zhang_and_Qinqiong_Zhang.pdf. 